\title{
UPAYA KEPALA MADRASAH DALAM MENINGKATKAN EKSISTENSI MADRASAH IBTIDAIYAH SWASTA
}

\author{
Japaruddin $^{1}$, Hamengkubuwono ${ }^{2}$, Kusen ${ }^{3}$, Jumira Warlizasusi ${ }^{4}$, \\ Murni Yanto ${ }^{5}$, Irwan Fathurrochman ${ }^{6}$ \\ Pascasarjana Institut Agama Islam Negeri (IAIN) Curup 1,2,3,4,5,6 $^{2}$ \\ kusenpasca1969@gmail.com ${ }^{3}$
}

\begin{abstract}
ABSTRAK
Penelitian ini bertujuan untuk mengetahui bagaimana upaya kepala madrasah terhadap peningkatan eksistensi Madrasah Ibtidaiyah Swasta (MIS) 01 Kepahiang. Penelitian ini menggunakan pendekatan kualitatif dengan metode analisis deskriptif, pengumpulan data melalui teknik, wawancara, observasi dan dokumentasi. Hasil penelitian menunjukkan bahwa upaya yang dilakukan kepala madrasah melalui perbaikan manajemen madrasah sehingga mengelola madrasah berjalan semakin baik. Untuk melaksanakan upaya tersebut melibatkan semua komponen dalam madrasah sehingga upaya kepala madrasah dapat dilaksanakan dengan baik. Kepala madrasah mendapat dukungan positif pada para guru dan masyarakat sehingga dapat mengembangkan eksistensi madrasah. Faktor pendukung internal kondisi madrasah adalah comfort untuk bekerja sehingga kegiatan dapat berjalan dengan baik. Kemudian secara eksternal masyarakat mendukung adanya kegiatan pembelajaran. Hambatannya adalah kurang berjalannya waktu kegiatan pada madrasah secara optimal sehingga sulit untuk melakukan penerapan manajemen untuk meningkatkan eksistensi madrasah yang efeketif dan efisien.
\end{abstract}

Kata Kunci: Upaya Kepala Madrasah, Peningkatan Eksistensi Madrasah.

\begin{abstract}
This study aims to determine how the efforts of the head of madrasah to improve the existence of Private Madrasah Ibtidaiyah (MIS) 01 Kepahiang. This research uses a qualitative approach with descriptive analysis methods, data collection through techniques, interviews, observation and documentation. The results showed that the efforts made by the head of madrasah were through improving madrasah management so that managing madrasahs went better. To carry out this effort involves all components in the madrasah so that the efforts of the head of the madrasah can be carried out properly. The head of madrasah receives positive support from teachers and the community so that they can develop the existence of the madrasah. The internal supporting factor for the condition of the madrasah is comfort to work so that activities can run well. Then externally the community supports the learning activities. The obstacle is the lack of optimal madrasah activity time, making it difficult to implement management to improve the existence of an effective and efficient madrasah.
\end{abstract}

Keywords: Efforts of the Head of Madrasah, Increasing the Existence of Madrasas. 


\section{PENDAHULUAN}

Pendidikan Nasional bertujuan mempersiapkan out-put di bidang pendidikan dalam memasuki era global. Sementara pendidikan selama ini masih menggunakan standart nilai raport sebagai standart baku. Anaknya berhasil manakala raportnya tidak ada yang merah, secara kelembagaan madrasah belum mampu menyediakan stok seperti apa yang diharapkan. Berdasarkan realita kebutuhan masyarakat, pendidikan harus mampu mengembangkan berbagai ranah pendidikan (pengetahuan, keterampilan dan sikap). Hasil belajar dapat ditandai oleh tiga ranah afektif, kognitif dan psikomotorik. Berkenaan dengan hal tersebut, kualitas pendidikan dapat berhasilsalah satunya apabila kepala madrasah memahami manajamen sehingga dapat diilmplentasikan dalam tugas dengan tunjuan guru mempunyai kompetensi yang profesional. Kompetensi merupakan seperangkat pengetahuan, ketrampilan, dan perilaku yang harus dimiliki, dihayati, dikuasai, dan diwujudkan dalam melaksanakan tugasnya sehingga profesional guru dapat dikembangkan.

Keberhasilan kualitas pendidikan sangat ditentukan oleh kepemimpinan kepala madrasah dalam mengelola kepala, sarana dan prasarana, serta siswa. Kepala sebagai tokoh sentral dalam madrasah perlu mendapat perhatian yang khusus serta perlakuan yang istemewa agar kepala dapat memaksimalkan perannya. Demikian halnya dengan pengelolaan sarana dan prasarana madrasah dan siswa. Penggunaan sarana dan prasarana sebagai alat penunjang keberhasilan pendidikan perlu mendapat pengelolaan yang baik. Terlebih dengan siswa sebagai objek pendidikan yang memiliki berbagai macam karakter dan latar belakang tentunya membutuhkan pengelolaan yang baik. Namun dalam kenyataannya banyak kepala madrasah yang belum mampu memaksimalkan peran kepala, pengelolaan sarana dan prasarana, serta pengelolaan siswa dengan baik.

Madrasah Ibtidaiyah Swasta 01 Kepahiang, belum maksimal dalam peningkatan pembelajaran, sehingga hasil belajar peserta didik belum meningkat. Dengan kondisi tersebut maka kepala madrasah perlu untuk melakukan upaya agar peningkatan hasil belajar peserta didik dengan baik, melalui, memperbaiki manajemen madrasah dalam peningkatan eksistensi madrasah, serta faktor apa yang mendukung dan menghambat kepala madrasah dalam melaksanakan upaya di Madrasah dalam meningkatkan eksistensi 04 Kepahiang.

Eksistensi madrasah Ibtidaiyah sendiri tidak terlepas dari peran strategis dan partisipasi masyarakat baik dalam hal penyusunan atau perencanaan program strategis madrasah maupun dalam hal pengawasan program madrasah (Agustina, 2020). Keterlibatan masyarakat dalam pendidikan madrasah secara garis besar dibagi menjadi dua, yaitu : 1) keterlibatan secara individual, seperti membuka kesempatan dan konsultasi seluas luasnya bagi orang tua peserta didik untuk datang ke madrasah. Peran Partisipasi Masyarakat 2) keterlibatan secara organisatoris, yaitu keterlibatan melalui komite madrasah, organisasi alumni, dunia usaha/kerja, dan melalui hubungan dengan instansi lain (Pratiwi, 2020). 
Bentuk keterlibatan masyarakat secara organisatoris, misalnya untuk kegiatan pembangunan fisik, orang tua peserta didik yang arsitektur diminta bantuannya membuat design bangunan, pemusik, pelukis, dramawan, dan olahragawan dilibatkan dalam kegiatan ekstra kurikuler, praktisi hukum dilibatkan dalam masalah hukum, dan tata tertib dan profesi lain yang mendukung kemajuan pendidikan di madrasah (Akhyar, 2019).

Melihat realitas yang terjadi di lokasi penelitian, bahwa kedua komponen yaitu madrasah dan masyarakat merupakan dua komunitas yang saling melengkapi bahkan ikut memberikan warna terhadap segala prestasi yang diraih madrasah. Madrasah mempunyai peran dalam proses pelestarian dan pemindahan nilai-nilai kultur pendidikan, ilmu pengetahuan , teknologi, seni, dan agama yang dianut para guru dan peserta didiknya kepada generasi penerus sebagaimana yang diharapkan oleh masyarakat. Demikian halnya dengan masyarakat, mereka mempunyai peran yang strategis dalam membantu madrasah untuk merealisasikan segala program peningkatan mutu pendidikan (Hidayat, \& Ibrahim, 2019).

\section{METODE PENELITIAN}

Penelitian ini menggunakan pendekatan kualitatif dengan metode analisis deskriptif. Penelitian deskriptif adalah penelitian yang bersifat menggambarkan, menguraikan suatu hal secara apa adanya. Penelitian ini dilakukan di Madrasah Ibtidaiyah Swasta 01 Kepahiang pada tahun 2019. Subyek penelitian adalah pengurus Kepala Madrasah Ibtidaiyah Swasta 01 Kepahiang dan wakil kepala sekolah bidang Kurikulum. Proses pengumpulan data dilakukan melalui wawancara mendalam, observasi dan dokumentasi terhadap dokumen dokumen yang mendukung ketersediaan data dalam penelitian ini. Studi dokumentasi digunakan untuk melengkapi data penelitian yang dibutuhkan. Triangulasi sumber data digunakan untuk menguji keabsahan data, sedangkan teknik analisis data menggunakan teknik analisis data induktif.

\section{HASIL PENELITIAN}

\section{Upaya Kepala Madrasah terhadap Eksistensi Madrasah Ibtidaiyah Swasta}

Menjadi madrasah yang dijadikan pilihan masyarakat, tidak muncul dengan sendirinya namun ada dorongan dari madrasah itu sendiri, guru, pala madrasah juga dari luar madrasah yaitu masyarakat. Dorongan dari luar diri guru yaitu keberadaan kepala madrasah mempunyai tugas yang penting salah satunya adalah kemampuan kepala madrasa dalam meningkatkan kompetensi madrasah tersebut , sebagaimana penjelasannya bahwa kepala madrasah mempunyai upaya meningkatkan eksistensi Madrasah sehingga masyarakat dapat memberikan penilaian apa saja yang ingin lakukan untuk meningkatkan hasil belajar siswa, karena dengan persiapan pengajaran yang baik, semangat mengajar yang tinggi butuh persiapan yang baik, diantaranya, misalnya untuk praktek sholat yang 
dipersiapkan tempat shalat. Agar siswa dapat menjadi siswa yang agamis dalam kehidupan di lingkungan madrasah" (Kepala Madrasah MIS 01 Kepahiang, 2020).

Mutu madrasah menjadi taruhan ketika menghadapi tuntutan-tuntutan pembelajaran dewasa ini karena tuntutan tersebut merefleksikan suatu kebutuhan yang semakin kompleks yang berasal dari siswa dan lingkungan, tidak sekedar kemampuan guru menguasai pelajaran semata tetapi juga kemampuan lainnya yang bersifat psikis, strategis dan produktif. Tuntutan demikian ini hanya bisa dijawab oleh kemampuan kepala madrasah yang kinerjanya tinggi.

\section{Realisasi Kepala Madrasah terhadap Eksistensi Madrasah Ibtidaiyah Swasta}

Mutu madrasah salah satunya dipengaruhi oleh kemampuan kepala madrasah dalam mengelola madrasah sehingga dengan pengelolaan madrasah maka penguasaan bahan ajar yang akan diajarkan dapat diterima oleh peserta didik dengan baik. Penguasaan bahan ajar oleh kepala madrasah adalah kemampuan yang dimiliki kepala madrasah dalam menerapkan sejumlah fakta, konsep, prinsip dan ketrampilan untuk menyelesaikan dan memecahkan soalsoal atau masalah yang berkaitan dengan pokok bahasan yang diajarkan.

Sehubungan dengan hal tersebut Kepala Madrasah menjelaskan bahwa Kepala madrasah sebagai pendidik memiliki komitmen bahwa tugas utamanya adalahmengarahkan dan membimbing para guru dan peserta didik agar semangat untuk belajar. Semangat belajar peserta didik dapat berjalan dengan baik jika kondisi belajar dikelola dengan baik, suasana belajar yang nyaman, tidak ribut (Kepala Madrasah MIS 01 Kepahiang, 2020).

Lebih lanjut dijelaskan bahwa pengelolaan pembelajaran menjadi hal penting karena berkaitan langsung dengan aktivitas belajar siswa. Upaya kepala madrasahmemberikan arahan kepada para guru untuk menguasai bahan ajar yang akan diajarkan, merencanakan dan melaksanakan kegiatan pembelajaran dengan optimal dapat terwujud jika dalam diri kepala madrasah tersebut ada dorongan dan tekad yang kuat untuk menjalankan tugasnya dengan baik (Kepala Madrasah MIS 01 Kepahiang, 2020).

Dengan demikian, jika dikaitkan dengan pengertian kemampuan mengelola pembelajaran yang telah dijelaskan di atas, maka salah tugas kepala madrasah adalah mengupayakan dan memberdayakan semua aspek yang terlibat dalam kegiatan pembelajaran, yaitu: kepala madrasah, siswa, bahan ajar, sarana pembelajaran, dan lingkungan belajar sehingga proses pembelajaran dapat berlangsung efektif. Kondisi pembelajaran yang efektif dapat tercapai jika kepala madrasah mampu mengatur siswa dan sarana pembelajaran, mampu menjalin hubungan interpersonal dengan siswa serta mengendalikannya dalam suasana yang menyenangkan untuk mencapai tujuan pembelajaran. Kondisi pembelajaran yang efektif akan mempengaruhi kualitas pelaksanaan pembelajaran. Dengan demikian dapat dinyatakan bahwa kemampuan mengelola pembelajaran merupakan upaya kepala madrasah dalam mengelola pembelajaran selama proses 
pembelajaran berlangsung dengan dimensi: (1) menciptakan dan memelihara kondisi pembelajaran yang optimal, (2) melaksanakan kegiatan pembelajaran, (3) membina hubungan yang positif dengan siswa selama proses pembelajaran berlangsung.

Sehubungan dengan hal tersebut wakil kepala madrasah menjalaskan sebagai berikut kepala madrasah dalam menjalankan tugasnya harus dapat menghayati dan menjiwai tugasnya sebagai kepala madrasah, sebab kepala madrasah yang kurang menghayati dan menjiwai tugasnya sebagai kepala madrasah maka kepala madrasah kurang memahami apa yang diinginkan oleh peserta didik (Kepala Madrasah MIS 01 Kepahiang, 2020).

Lebih lanjut dijelaskan bahwa untuk dapat menghayati dan menjiwai tugasnya sebagai kepala madrasah, maka kepala madrasah harus selalu mengikuti perkembangan ilmu pengetahuan, terutama perkembangan teknologi yang tidak bisa dihindari dalam dunia pendidikan, untuk itu kepala madrasah terus berupaya meningkatkan kompetensi profesionalits agar tidak tertinggal dalam menyampaikan materi (Kepala Madrasah MIS 01 Kepahiang, 2020).

Berdasarkan hasil wawancara di atas dapatlah dipahami bahwa kepala madrasah memiliki kemampuan untuk meningkatkan Mutu madrasah melalui pengelolaan pembelajaran yang tentu saja harus dimiliki kemampuan pada diri kepala madrasah, sebab dengan kemampuan untuk mengelolah madrasah maka proses pembelajaran akan semakin baik.

\section{Organizing Kepala Madrasah terhadap Eksistensi Madrasah}

Keberhasilan madrasah merupakan target yang harus dicapai oleh kepala madrasah dan tersebut merupakan keberhasilan kepala madrasah. Kepala madrasah yang berhasil apabila mereka memahami keberadaan madrasah sebagai organisasi yang kompleks dan unik, serta mampu melaksanakan peranan kepala madrasah sebagai seseorang yang diberi tanggung jawab untuk memimpin madrasah

Dalam rangka melakukan peran dan fungsinya sebagai monitoring dan evaluasi, kepala madrasah memiliki strategi yang tepat untuk menjalin hubungan yang harmonis dengan lingkungan, mencari gagasan baru, mengintegrasikan setiap kegiatan, memberikan teladan kepada seluruh tenaga kependidikan di madrasah, dan mengembangkan model-model pembelajaran yang inovatif. Kepala madrasah sebagai pelaksana monitorng dan evaluasi akan tercermin dari cara-cara ia melakukan pekerjaannya secara konstuktif, kreatif, delegatif, integratif, rasional dan objektif, pragmatis, keteladanan, disiplin, serta adaptabel dan fleksibel. Berdasarkan hasil wawancara dengan Kepala Madrasah mengatakan bahwa Ada beberapa kepala madrasah diikutsertakan dalam sejumlah pelatihan pengembangan kompetensi kepala madrasah. Beliau juga menegaskan pelatihan ini berguna bagi kepala madrasah kepala madrasah untuk lebih mengembangkan potensinya terutama dalam mengelola kegiatan pembelajaran. Pengelolaan 
pembelajaran secara efektif juga dapat tercapai jika kepala madrasah mampu membina hubungan positif dengan siswa (Kepala Madrasah MIS 01 Kepahiang, 2020).

\section{Controlling Kepala Madrasah terhadap Eksistensi Madrasah}

Peningkatkatan Mutu madrasah, maka kepala madrasah fokus pada beberapa komponen. Seperti yang telah disampaikan Kepala Madrasah. Kami berupaya selalu berusaha mendapatkan hasil yang terbaik. Dengan keterbatasan yang ada kami ingin meningkatkan kompetensi profesionalitas kepala madrasah. Sikap jujur kepala madrasah, penghargaan terhadap hasrat dan kebutuhan kepala madrasah untuk maju, iklim komunikasi demokrasi yang serasi dan manusiawi antara pimpinan dan karyawan. Dan yang menjadi kendala dalah volume upah kerja yang belum memenuhi kebutuhan kepala madrasah, keterbatasan sarana yang menunjang bagi kenyamanan, suasana mengajar yang kurang menumbuhkan semangat (Kepala Madrasah MIS 01 Kepahiang, 2020). Berdasarkan pernyataan ini jelas bahwa ada komitmen yang kuat mengenai upaya Kepala Madrasah dalam meningkatkan mutu madrasah.

\section{PEMBAHASAN}

\section{Upaya Kepala Madrasah terhadap Eksistensi Madrasah Ibtidaiyah Swasta}

Berdasarkan hasil penelitian ini diperoleh data bahwa keberhasilan dalam proses pembelajaran dapat dilihat ketika lulusan tersebut memiliki daya saing Dengan demikian keberadaan Madrasah sangat berkaitan dengan potensi daerah, corak pengembangan sangat dipengaruhi oleh nuansa daerah, sehingga lulusan tersebut dapat diterima di madrasa dan sekolah lanjutan. Tugas dan tanggung jawab tersebut lebih luas dari sekedar hanya membuat peserta didik menjadi tahu dan memahami bahan ajar yang diberikan, yaitu menjadikan peserta didik menjadi manusia terdidik yang memahami perannya sebagai manusia, sehingga bermanfaat bagi diri dan lingkungannya yang selama ini menjadi wacana dalam meningkatkan mutu pendidikan. Persoalan pendidik adalah persoalan pendidikan, dan persoalan pendidikan adalah persoalan bangsa. Begitulah kalangan praktisi pendidikan menggiring isu tentang pendidik dalam upaya meningkatkan mutu.

\section{Realisasi Kepala Madrasah terhadap Eksistensi Madrasah Ibtidaiyah Swasta}

Pendidik merupakan salah satu komponen yang penting dan utama dalam proses pembelajaran yang ikut berperanserta dalam usaha pembentukan sumber daya manusia yang bermutu. Menurut Djamara dalam Lathoib Husin menjelaskan bahwa guru adalah semua orang yang berwenang dan bertanggung jawab untuk membimbing dan membina anak didik, baik secara individual mapun klasikal di madrasah/madrasah.

Berdasarkan penjelasan di atas bahwa seorang pendidik agar mampu menjalankan tugasnya dalam mendidik dan membimbing, maka pendidik perlu 
menguasan wawasan yang luas dalam hal mendidik dan membimbing, yang dikenal dengan kompetensi guru. Kompetensi guru merupakan suatu kemampuan yang mutlak dimiliki oleh guru sehingga dalam menjalankan tugasnya sesuai dengan tuntutan perkembangan zaman.

\section{Organizing Kepala Madrasah terhadap Eksistensi Madrasah}

Keberadaan seorang pemimpin dalam suatu organisasi sangat diperlukan dalam mencapai tujuan sebab pemimpin merupakan motor penggerak untuk mengimplementasikan tujuan dari organisasi. Di dalam tugas menggerakkan meliputi kegiatan-kegiatan: memberi petunjuk, membimbing, mendidik, membina, mengarah-kan, dan sebagainya.

Teori tentang kepemimpinan memang terus berkembang seiring dengan perkembangan zaman, dan sampai saat ini terdapat empat fase pendekatan. Pertama, pendekatan berdasarkan sifat-sifat (trait) kepribadian umum yang dimiliki oleh seorang pemimpin. Kedua, berdasarkan pendekatan tingkah laku pemimpin. Ketiga, berdasarkan pendekatan situasional. Keempat, pendekatan pengaruh kewibawaan.

Kepala madrasah adalah orang yang membawahi sekelompok anggota staf. Membawahi bukan berarti berkuasa dan dapat bertindak sewenang-wenang, melainkan dalam arti kepala madrasah berada di atas dalam tanggung jawab dan harus selalu dapat melihat ke bawah, fungsi kepala madrasah dalam hal ini adalah memberikan bimbingan dan penyuluhan kepada pendidik agar dapat melaksanakan tugasnya sebagai pendidik dan pengajar secara efektif dan efisien. Usaha dan kegiatan dalam memberi kesempatan yang seluas-luasnya kepada pendidik untuk tumbuh dan kembang secara profesional merupakan tugas dan tanggung jawab kepala madrasah dalam bidang supervisi.

\section{Controlling Kepala Madrasah terhadap Eksistensi Madrasah}

Pemimpin harus mampu menunjukkan perilkau kepemimpinan sehingga mampu meyakinkan dan menggerakkan orang lain agar mau bekerja sama di bawah kepemimpinannya sebagai suatu tim untuk mencapai suatu tujuan tertentu. Controlling yang dilakukan oleh kepala madrasah adalah dengan meningkatkan kemapuan kepemimpinan sebagai bagian penting dalam manajemen,. Kepemimpinan merupakan kemampuan yang dipunyai seseorang untuk mempengaruhi orang-orang lain agar bekerja mencapai tujuan dan sasaran. Manajemen mencakup kepemimpinan, tetapi juga mencakup fungsi-fungsi lain seperti perencanaan, pengorganisasian, dan pengawasan

\section{Eksistensi Madrasah}

Sebagai lembaga pendidikan Islam, harus mampu tampil dan eksis di tengah kebutuhan masyarakat terhadap lembaga pendidikan Islam, dalam hal ini kepala madrasah telah sanggup menunjukkan eksistensi madrasah ditengah persaingan 
lembaga pendidikan swasta di Kabupaten Kepahyang, berdasarkan kepada penejalsan dari Hasbullah (2009) bahwa eksistensi madrasah merupakan wadah berlangsungnya proses pendidikan Islam yang bersamaan dengan proses pembudayaan. Oleh karena itu lembaga pendidikan Islam harus sesuai dengan tuntutan dan aspirasi masyarakat, sebab tanpa memperhatikan yang demikian itu, maka untuk mencapai keberhasilan sulit di capai.

\section{SIMPULAN}

Upaya yang dilakukan kepala madrasah melalui perbaikan manajemen madrasah sehingga mengelola madrasah berjalan semakin baik. Untuk melaksanakan upaya tersebut melibatkan semua komponen dalam madrasah sehingga upaya kepala madrasah dapat dilaksanakan dengan baik. Kepala madrasah mendapat dukungan positif pada para guru dan masyarakat sehingga dapat mengembangkan eksistensi madrasah. Faktor pendukung internal kondisi madrasah adalah comfort untuk bekerja sehingga kegiatan dapat berjalan dengan baik. Kemudian secara eksternal masyarakat mendukung adanya kegiatan pembelajaran. Hambatannya adalah kurang berjalannya waktu kegiatan pada madrasah secara optimal sehingga sulit untuk melakukan penerapan manajemen untuk meningkatkan eksistensi madrasah yang efeketif dan efisien.

\section{DAFTAR PUSTAKA}

Agustina, A. (2020). Manajemen Peningkatan Mutu Berbasis Madrasah di Madrasah Ibtidaiyah Negeri 5 Bulukumba. El-Idare: Jurnal Manajemen Pendidikan Islam, 6(1), 13-26.

Akhyar, S. (2019). Manajemen Mutu Madrasah Ibtidaiyah II Palembang. Studia Manageria, 1(2), 133-148.

Departemen Pendidikan Nasional. 2002. Indikator Keberhasilan Kepala SLTP dan SMU. 1999. Departemen Pendidikan dan Kebudayaan Propinsi Jawa Tengah.

Hidayat, H., \& Ibrahim, I. (2019). Upaya Kepala Madrasah dalam Mengembangkan Lembaga Pendidikan di Madrasah Ibtidaiyah Nashriyah Desa Tanjung Baru. Studia Manageria, 1(2), 99-118.

Pratiwi, V. (2020). Persepsi Masyarakat Atas Adanya Madrasah Ibtidaiyah AlHijrah Ujung Tanjung Kecamatan Tulung Selapan Ogan Komering Ilir (OKI) Sumsel (Doctoral Dissertation, Universitas Islam Negri Raden Fatah Palembang). 